\title{
Effects of Organic Mulch on Soil Moisture and Nutrients in Karst Area of Southwest China
}

\author{
Rui Li ${ }^{1,2 *}$, Qinggui Li ${ }^{1,2}$, Jinjin Zhang, ${ }^{1,2}$ Zhongxian Liu ${ }^{3}$, Lidong Pan ${ }^{1,2}$, \\ Kai Huang, ${ }^{1,2}$ Linqing Zhang, ${ }^{1,2}$ \\ ${ }^{1}$ School of Karst Science, Guizhou Normal University, Guiyang, Guizhou, China \\ ${ }^{2}$ State Engineering Technology Institute for Karst Desertification Control, Guiyang, Guizhou, China \\ ${ }^{3}$ Guizhou Provincial Monitoring Station of Soil and Water Conservation, Guiyang, China
}

Received: 30 December 2019

Accepted: 23 March 2020

\begin{abstract}
Based on the typical engineering water shortage and soil degradation of sloping farmland in the karst area of southwest China, this experiment is to explore the suitable organic mulch materials and application rate and to provide theoretical reference for the regional soil moisture conservation and fertility enhancement. The maize monoculture was set as control (CK), five straw mulch treatments $(20 \%, 40 \%, 60 \%, 80 \%, 100 \%$, SM1-SM5) and four biochar mulch treatments $(25 \%, 50 \%, 75 \%, 100 \%$, BM1-BM4), which were set according to mulch application rate from low to high, and alfalfa, chicory and ryegrass intercropping in maize were set as 3 living mulches (LM1-LM3), 13 treatments in total. Observation of soil moisture, total organic carbon (TOC), total nitrogen (TN), total phosphorus (TP) and total potassium (TK) in the plough layer were carried out in 2018. When straw mulch application rate reached SM5, the soil moisture reached the maximum, which was significantly higher than CK and SM1-SM3 $(p<0.05)$, but not significantly higher than SM4 $(p>0.05)$; biochar and living mulch did not significantly improve the moisture; the overall water conservation effect of straw mulch was better than that of biochar and living mulch. Soil TOC, TN and TP with high straw and biochar mulch application rate was significantly higher than $\mathrm{CK}$, however, the increase of straw and biochar mulch had no significant effect on TK; TN of LM1 was significantly higher than CK, LM2 and LM3 $(p<0.05)$. Among the three types of organic mulches, the TOC was high under straw and biochar mulch, and the TOC, TN and TP under biochar mulch were the largest, which was significantly higher than that of LM $(p<0.05)$. The results indicated that straw mulch played an important role in water conservation and fertility enhancement, and about $6 \mathrm{Mg} \mathrm{ha}^{-1}$ of straw mulch could be an appropriate reference mulch application rate for karst areas in Southwest China.
\end{abstract}

Keywords: karst area, organic mulch, sloping farmland, soil moisture, total organic carbon

*e-mail: rlifer@126.com 


\section{Introduction}

Land degradation is a global environmental and development problem. Almost one-fifth of degraded land is cultivated land, accounting for more than $20 \%$ of all cultivated land area [1]. As the core content of land degradationand, soil degradation, which has a direct impact on food safety, environmental quality and human and animal health, has become the most important part of global change research [2]. In the karst area of Southwest China, due to the special karst environment and the unreasonable utilization of land resources by farming and animal husbandry activities, the problems of regional soil erosion, decrease in soil quality, land rocky desertification and engineering water shortage are particularly prominent, which seriously restrict the development of local agriculture. Soil nutrients, including organic carbon, nitrogen, phosphorus and potassium, are necessary nutrients for crop growth and development, and are decisive factors for soil fertility [3]. As the transport carrier for crops to absorb soil nutrients, soil moisture is the key factor to affect crop growth and development and crop yield [4]. Sloping farmland accounts for a large proportion of the total area of cultivated land in karst areas of Southwest China, and as an important source of soil and water loss [5], its serious soil and water loss aggravates the poor soil. Therefore, it is of great significance to study the effect of organic mulch on soil nutrients and moisture in the karst area of Southwest China for the sustainable development of regional agriculture.

There are two main types of mulching: the degradable organic mulch and the non- degradable inorganic mulch. In recent years, both types of mulches have been continuously promoted in agricultural farming practices around the world [6-7]. Hartwig et al. believed that organic mulch should include "living organic mulch" in addition to traditional organic mulch [8]. According to Hartwig et al, "living organic mulch" refers to plants that are planted prior to or at the same time as the main crop and serve as living ground mulch throughout the growing season. Therefore, the organic mulch in this paper includes not only traditional organic mulch, but also living mulch.

The improvement of soil environment by organic mulch has been widely confirmed. The effect of organic mulch on soil fertility is especially obvious, and the type, duration and amount of organic mulch play an important role in the process of improving soil fertility. It was found that after 5 years of application of mulching compared with other treatments, wood-based mulch still had a significant impact on soil fertility in forest land, and the regulation of soil erosion driven by hydraulic force on steep slopes was the most effective. Therefore, in vegetation restoration areas, wood-based mulch might play an important role in improving soil quality [9]. Similar studies have also found that longterm organic mulch could improve the organic carbon stock of forest ecosystem for intensively managed bamboo forests [10]. Under the condition of longterm organic mulch, the mulching material is easy to decompose completely, so it is easy to release nutrients to the soil. However, the experiment of straw returning to the field in the North China agricultural region for 32 years found that the total phosphorus and organic matter of the soil with long-term application of chemical fertilizer and straw mulch increased significantly, but the total nitrogen did not change significantly, while the total potassium even decreased [11]. No significant change of total nitrogen or even decrease of potassium may be related to the initial content of nitrogen and potassium in the soil [12]. The nutrients returned to the soil by organic mulching materials are quite different due to different materials. For example, the legume residues mulch with a relatively low C-to-N ratio can lead to nitrogen mineralization, while cereal residues mulch with a relatively high $\mathrm{C}$-to- $\mathrm{N}$ ratio can temporarily immobilize $\mathrm{N}$ [13]. It can be seen that the decrease of the concentration of mineral nitrogen in the soil can be explained by the fixation of nitrogen in the decomposition process of non- legume residues; living mulch using living plants as a kind of mulching material can also exert significant impact on soil fertility. The experiment of living mulch on cultivated land, forest land and orchard showed that the above part of the living mulch could increase the canopy density of the surface vegetation, while the underground roots could produce secretions to accelerate the production of soluble organic carbon and nitrogen and improve the microbial activity and diversity of the soil [1416], so living mulch could significantly reduce the evaporation of soil water and improve the content of soil nutrients [17-19]. In general, the relationship between organic mulch application rate and soil nutrient content is relatively certain, that is, with the increase of organic mulch application rate, the content of soil organic carbon, mineral nitrogen, available potassium, exchangeable potassium and available phosphorus and other nutrients tends to increase $[12,20]$.

Regulating soil moisture is another important aspect of the improvement of soil environment by organic mulch. Organic mulch can not only provide a buffer against high and low temperature, but also enhance the water holding capacity of soil by improving soil bulk density, porosity and aggregate stability [21-24]. In arid and semi-arid areas, the soil moisture content of cultivated land is a key factor affecting crop yield. Therefore, similar to the importance of organic mulch on soil nutrient, the impact of organic mulch on soil moisture is also the focus of many researchers. The level of organic mulch application rate will directly affect the evaporation, infiltration and runoff of soil water [25]. By studying the effects of organic mulch on soil characteristics and greenhouse gas emissions under different tillage systems, Nawaz et al. found that soil evaporation decreased with the increase of mulching amount, and soil infiltration increased with the increase of mulching application rate, thus it can effectively 
reduce slope runoff and increase soil available water content [26].

Although the karst area in Southwest China is located in the subtropical zone, the karst is generally developed and the soil and water loss is serious, so the problem of poor soil and engineering water shortage is prominent. Many studies have confirmed the effectiveness of organic mulch to improve soil environment, but there are few reports in karst area of Southwest China, and there are fewer field experiments to explore the impact of different organic mulch application rates and types of mulching materials on soil environment. Based on the field location observation, considering the availability of organic mulching materials and the development of agriculture and animal husbandry in the experimental area, the effects of straw mulch, biochar mulch and living mulch on soil moisture and nutrients were studied. The purposes of this study are: 1) to explore effects of different straw and biochar mulch application rate on soil environment; 2) to analyze the impact of different living mulch on the soil environment; 3) to compare the differences of the effects of straw, biochar and living mulch on soil environment; 4) to explore the appropriate straw mulch application rate in karst areas of Southwest China; 5) to fill in the deficiencies of field experiments in Southwest China, and to provide a theoretical reference for the application and promotion of organic mulch in regional farming practice.

\section{Materials and Methods}

\section{Experimental Site}

The study area is located in Jinlan Town, Qianxi County, Guizhou Province, China (hereinafter referred to as "Jinlan demonstration area"), with the longitude of $105^{\circ} 47^{\prime}-106^{\circ} 26^{\prime}$, the latitude of $26^{\circ} 45^{\prime}-27^{\circ} 21^{\prime}$, it was shown in Fig. 1. The expressway from Guiyang to Qianxi (S82) passes through Jinlan demonstration area, which is only an hour and 20 minutes' drive from Guiyang, so the traffic is very convenient. The climate in this area is subtropical warm and humid, with abundant rainfall. The average annual rainfall is generally over $1000 \mathrm{~mm}$, with simultaneous rain and heat. The annual temperature range is relatively small, and the annual average temperature is $14.2^{\circ} \mathrm{C}$. The lowest monthly temperature and the highest monthly temperature are generally January and July, and the annual average sunshine duration is up to $1066 \mathrm{~h}$. During the experimental observation period (2018), the annual precipitation in the study area was $936.26 \mathrm{~mm}$, mainly concentrated in May to October, reaching $665.4 \mathrm{~mm}$, accounting for $71 \%$ of the annual precipitation; the average temperature in 2018 was $15.36^{\circ} \mathrm{C}$, and the temperature in May to September was relatively high, all above $20^{\circ} \mathrm{C}$, it was shown in Fig. 2.



Fig. 1. Geographical location of the study area. 


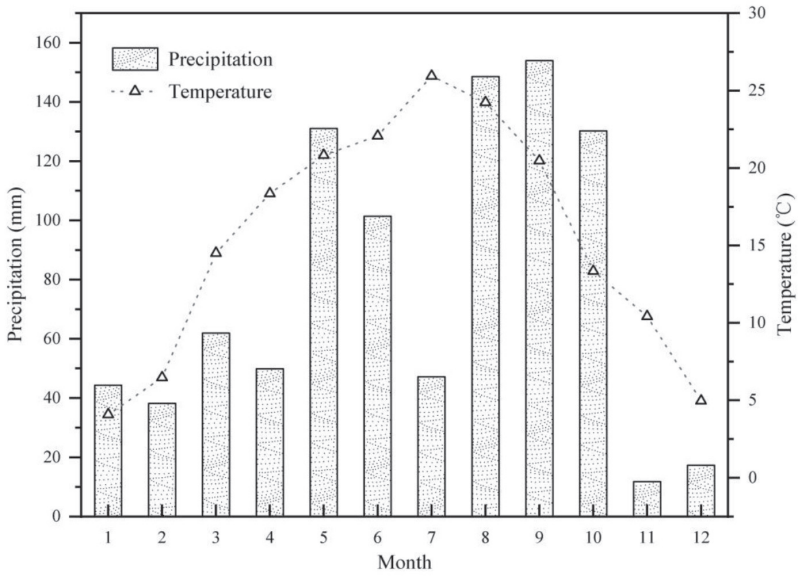

Fig. 2. Precipitation and temperature in the study area in 2018.

The total land area of Jinlan demonstration area is $555.8 \mathrm{ha}$, of which the rocky desertification land area is 478 ha, accounting for $86 \%$ of the total land area; the cultivated land area is 239 ha, of which the rocky desertification sloping farmland area is 191 ha, accounting for $80 \%$ of the total cultivated land area. The soil types in this area are mainly yellow soil and yellow lime soil, among which yellow soil is zonal soil, while yellow lime soil is staggered distribution.

\section{Experimental Design}

The preparation for field situ observation started in December 2017, mainly including the construction of experimental plot, land preparation, maize planting, herbage planting, straw and biochar mulching. The specifications of the experimental plot were $3 \mathrm{~m} * 12$ $\mathrm{m}$, it was shown in Fig. 3. Before the construction of the plot, taking experimental area (maize monoculture land, $550 \mathrm{~m}^{2}$ ) as a sample plot unit, three soil samples were randomly collected to determine the background values of total organic carbon (TOC), total nitrogen (TN), total phosphorus (TP) and total potassium (TK) and soil bulk density, water moisture and compactness were measured by ring knife and compactness tester (SC-900) respectively, it was shown in Table 1. Based on the research purpose, straw and biochar were both mulched in the topsoil in the same year and ploughed into the soil in the next year. Straw was maize straw (cut to less than $2 \mathrm{~cm}$ ), biochar was rice husk biochar, and living mulch included maize intercropping alfalfa, chicory and perennial ryegrass. The maize was planted along the slope with the planting specification of
$100 \mathrm{~cm} * 70 \mathrm{~cm}$ (row spacing), $30 \mathrm{~cm}$ away from the edge of the plot, that is, 3 rows of maize were planted in each plot, with 17 holes in each row. The forage was planted in the way of strip sowing. Two rows of forage were planted in each plot. The forage was cut regularly in the growing period, and the stubble height was more than $5 \mathrm{~cm}$. The amount of fertilizer applied in each plot was the same and compound fertilizer was applied as the base fertilizer $\left(600 \mathrm{~kg} \mathrm{ha}^{-1}\right)$ in 2018. Other management systems are equivalent to local farming habits. After the preparation was completed, the field observation was carried out continuously from July 2018.

In the experimental design, no-till with straw mulch (SM), biochar mulch (BM) and living mulch (LM) were set as three organic mulch types, and no-till with traditional maize monoculture was set as control (CK). Among them, there were five different mulch application rate for straw mulch, namely $1.111,2.222$, 3.889, 5.556 and $6.944 \mathrm{Mg} \mathrm{ha}^{-1}$ (SM1-SM5), and straw weight referred to dry weight; four different mulch application rate for biochar mulch, namely 1.389, 2.778, 5.556 and $11.111 \mathrm{Mg} \mathrm{ha}^{-1}$ (BM1-BM4). According to the current situation of planting and animal husbandry in the demonstration area, maize intercropping alfalfa (LM1), chicory (LM2) and ryegrass (LM3) were set as three living mulch treatments, with a total of 13 treatments (including CK), it was shown in Fig. 3.

\section{Observation Index and Method}

The indexes measured in this experiment included total organic carbon (TOC), total nitrogen (TN), total phosphorus (TP), total potassium (TK) and soil moisture. Soil moisture was measured mainly with the method of ring knife, assisted by the soil moisture tester (FD-T type), and the depth of soil moisture measurement was $20 \mathrm{~cm}$. The sampling points for soil moisture were randomly arranged according to the parts of the plot. The upper, middle and lower parts were measured three times at a time, and the observation frequency was generally one time per 3 days. The observation period was from July 3 to December 10, 2018, during which 46 times of soil moisture are recorded. The sampling points of total organic carbon (TOC), total nitrogen (TN), total phosphorus (TP) and total potassium (TK) were set as soil moisture above, and sampling time was November 2018 after maize harvest. Total organic carbon, total nitrogen, total phosphorus and total potassium were determined by potassium dichromate volumetric method, semi- micro Kjeldahl method, perchloric acid sulfuric acid method, and flame

Table 1. Background value of relevant physicochemical indicators in test area.

\begin{tabular}{|c|c|c|c|c|c|c|}
\hline $\begin{array}{c}\text { Compactness } \\
(\mathrm{kPa})\end{array}$ & $\begin{array}{c}\text { Bulk density } \\
\left(\mathrm{g} \mathrm{cm}^{-3}\right)\end{array}$ & $\begin{array}{c}\text { Soil moisture } \\
\text { content } \\
(\%)\end{array}$ & $\begin{array}{c}\text { Total organic } \\
\text { carbon } \\
\left(\mathrm{g} \mathrm{kg}^{-1}\right)\end{array}$ & $\begin{array}{c}\text { Total nitrogen } \\
\left(\mathrm{g} \mathrm{kg}^{-1}\right)\end{array}$ & $\begin{array}{c}\text { Total phosphorus } \\
\left(\mathrm{g} \mathrm{kg}^{-1}\right)\end{array}$ & $\begin{array}{c}\text { Total potassium } \\
\left(\mathrm{g} \mathrm{kg}^{-1}\right)\end{array}$ \\
\hline 2251 & 1.27 & 20.22 & 10.54 & 0.57 & 0.62 & 19.91 \\
\hline
\end{tabular}




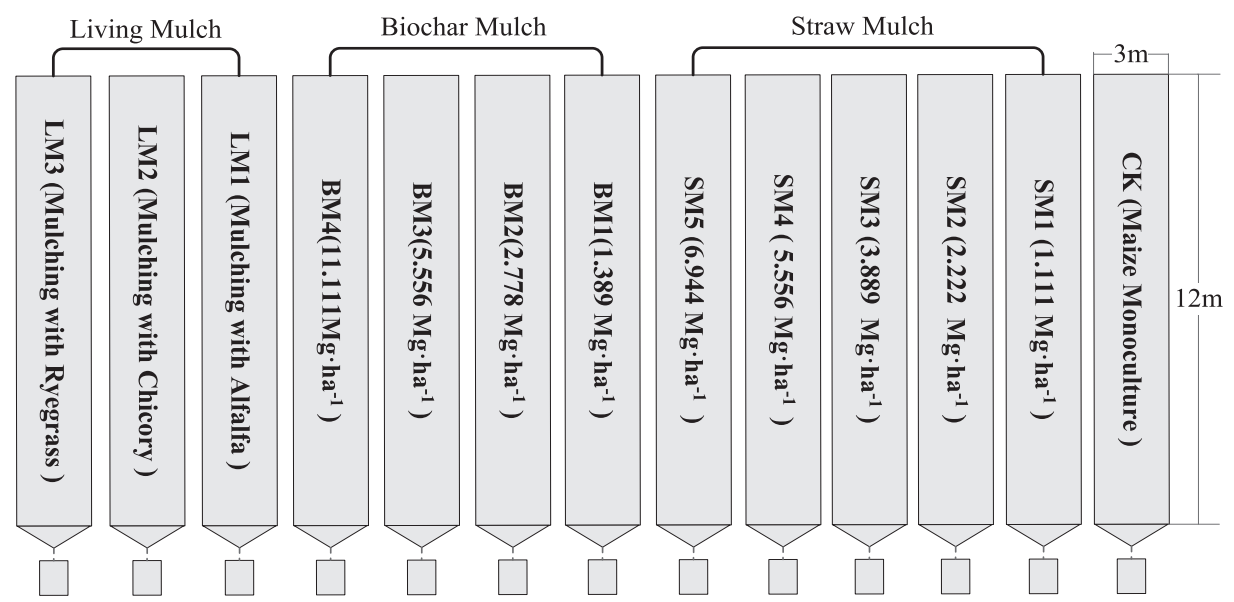

Fig. 3. Layout of treatments. CK no-till with maize monoculture treatment, SM1-SM5 and BM1-BM4 no-till with straw and biochar mulch application rate from low to high treatments respectively, LM1-LM3 no-till with alfalfa, chicory and ryegrass intercropping treatments.

photometer method respectively; one microclimate observation station was set in the demonstration area to record the meteorological indicators such as rainfall, temperature, wind speed and air humidity in the study area, and at the same time, an artificial rain gauge was set up to check the self-recording rain gauge.

\section{Statistical Analysis}

After calculating the sample mean value of soil TOC, TN, TP and moisture content under all treatments, SPSS22.0 - a statistical product and service solutions software, was used for one-way-ANOVA test and Pearson correlation analysis to obtain the difference significance of each sample mean value and the correlation coefficient between variables under the 0.05 significance level. Finally, Origin 2018, a kind of software for scientific drawing and data analysis, was used to make the relevant statistical analysis charts.

\section{Results}

\section{Effects of Organic Mulch on Soil Moisture}

\section{Effects of Straw Mulch on Soil Moisture}

It can be seen from Table 2 that there were differences in the moisture content of the cultivation layer under different straw mulch application rate. Generally, with the increase of straw mulch, the soil moisture content tended to increase. SM5 $>$ SM4 $>$ SM1 $>$ SM3 $>$ SM2 $>$ CK. CK, SM1 SM5 were 20.19\%, 20.56\%, $20.28 \%, 20.55 \%, 21.29 \%$ and $21.33 \%$, respectively. SM5 was the highest, $1.14 \%$ higher than CK. Multiple comparative analysis showed that compared with CK, SM1, SM2 and SM3 did not significantly increase the soil moisture content $(p>0.05)$, and there was no significant difference between SM1, SM2 and SM3 $(p>0.05)$, indicating that the effect of straw mulch on water conservation was not obvious when the mulch application rate was low (SM1-SM3); compared with CK, SM4 and SM5 significantly increased the soil moisture content $(p<0.05)$, and significantly higher than SM1, SM2 and SM3 $(p<0.05)$, but there was no significant difference between SM4 and SM5 ( $p>0.05)$. It can be seen that when the mulch application rate was high (SM4, SM5), the effect of straw mulch on soil moisture was obvious. When the mulch application rate reached 5.556 $\mathrm{Mg} \mathrm{ha}^{-1}$ (SM4), the soil moisture content significantly increased $(p<0.05)$, but when the straw mulch continued to increase to $6.944 \mathrm{Mg} \mathrm{ha}^{-1}$ (SM5), the soil moisture content did not increase significantly $(p>0.05)$ compared with SM4.

In order to further explore the impact of different straw mulch application rate on soil moisture, the

Table 2. Multiple comparison of soil moisture content under straw mulch.

\begin{tabular}{|c|c|}
\hline Treatment† & Soil moisture content $(\%)$ \\
\hline $\mathrm{CK}\left(0 \mathrm{Mg} \mathrm{ha}^{-1}\right)$ & $20.19 \pm 1.19 \ddagger \mathrm{b} \S$ \\
\hline $\mathrm{SM}_{1}\left(1.111 \mathrm{Mg} \mathrm{ha}^{-1}\right)$ & $20.56 \pm 1.71 \mathrm{~b}$ \\
\hline $\mathrm{SM}_{2}\left(2.222 \mathrm{Mg} \mathrm{ha}^{-1}\right)$ & $20.28 \pm 1.51 \mathrm{~b}$ \\
\hline $\mathrm{SM}_{3}\left(3.889 \mathrm{Mg} \mathrm{ha}^{-1}\right)$ & $20.55 \pm 1.13 \mathrm{~b}$ \\
\hline $\mathrm{SM}_{4}\left(5.556 \mathrm{Mg} \mathrm{ha}^{-1}\right)$ & $21.29 \pm 0.88 \mathrm{a}$ \\
\hline $\mathrm{SM}_{5}\left(6.944 \mathrm{Mg} \mathrm{ha}^{-1}\right)$ & $21.33 \pm 0.93 \mathrm{a}$ \\
\hline
\end{tabular}

$\uparrow \mathrm{CK}$, no-till without straw mulch; SM1-SM5, no-till with straw mulch application rate from low to high.

$\$$ Values are the mean \pm SD $(n=46)$.

$\S$ Different lowercase letters mean that there are significant differences between the six treatments at the $\mathrm{P}<0.05$ level. 
relationship between straw mulch application rate and soil moisture content was fitted by function model, as shown in Fig. 4. It can be seen that for different function fitting models, with the increase of straw mulch application rate, the soil moisture was generally on the rise, but the fitting effect of logistic model and polynomial fitting model (Fig. 4b and d) was better than that of linear and exponential model (Fig. $4 \mathrm{a}$ and c), which better reflected the relationship between straw mulch application rate and soil moisture. In addition, we can also know that about $6 \mathrm{Mg} \mathrm{ha}^{-1}$ of straw mulch could be an appropriate mulch application rate which could play a very good effect of soil moisture conservation (Fig. $4 b$ and d). However, it can be seen from Fig. 4 that the soil moisture content of SM1 was higher than that of SM2 and SM3, which might be caused by the incomplete cleaning of the accumulated straw to be mulched in the early stage of straw mulching preparation.

\section{Effects of Biochar Mulch on Soil Moisture}

It can be seen from Table 3 that with the increase of biochar mulch application rate, the soil moisture showed an overall slowly rising trend, BM4 $>$ BM $2>\mathrm{BM} 3>$ $\mathrm{CK}>\mathrm{BM} 1, \mathrm{BM} 4$ was the highest, reaching $20.42 \%, 0.23$ percentage points higher than $\mathrm{CK}$. Multiple comparative analysis found that compared with CK, BM1-BM4 did not significantly increase the moisture $(p>0.05)$, and
Table 3. Multiple comparison of soil moisture content under biochar mulch.

\begin{tabular}{|c|c|}
\hline Treatment $\dagger$ & Soil moisture content $(\%)$ \\
\hline $\mathrm{CK}\left(0 \mathrm{Mg} \mathrm{ha}^{-1}\right)$ & $20.19 \pm 1.19+\mathrm{a} \S$ \\
\hline $\mathrm{BM}_{1}\left(1.389 \mathrm{Mg} \mathrm{ha}^{-1}\right)$ & $20.18 \pm 1.70 \mathrm{a}$ \\
\hline $\mathrm{BM}_{2}\left(2.778 \mathrm{Mg} \mathrm{ha}^{-1}\right)$ & $20.23 \pm 1.54 \mathrm{a}$ \\
\hline $\mathrm{BM}_{3}\left(5.556 \mathrm{Mg} \mathrm{ha}^{-1}\right)$ & $20.21 \pm 1.38 \mathrm{a}$ \\
\hline $\mathrm{BM}_{4}\left(11.111 \mathrm{Mg} \mathrm{ha}^{-1}\right)$ & $20.42 \pm 0.73 \mathrm{a}$ \\
\hline
\end{tabular}

$\dagger \mathrm{CK}$, no-till without biochar mulch; BM1-BM4, no-till with biochar mulch application rate from low to high.

\# Values are the mean \pm SD $(n=46)$.

$\S$ Different lowercase letters mean that there are significant differences between the five treatments at the $\mathrm{P}<0.05$ level.

there was no significant difference between BM1, BM2, BM3 and BM4 $(p>0.05)$. It can be known that the effect of different application rate of rice husk biochar on the soil moisture in the plough layer was not obvious. Rice husk biochar with small bulk density could increase soil porosity, change soil aggregation, and enhance soil water infiltration capacity to a certain extent, thus increasing the soil moisture content of plough layer. The results showed that the short-term rice husk biochar mulch had a certain impact on soil moisture, but did not significantly improve soil moisture.
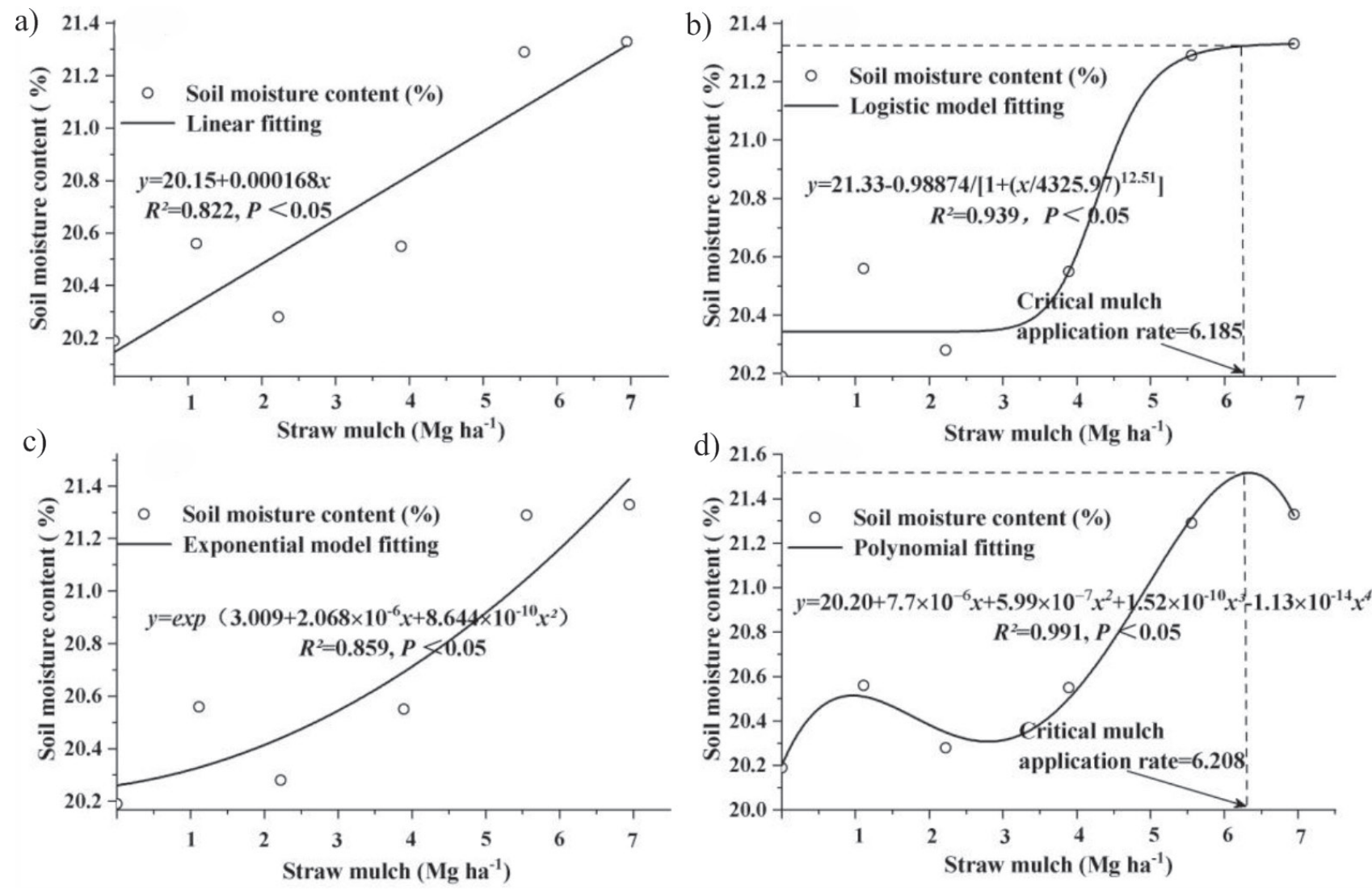

Fig. 4. Relationship between straw mulch application rate and soil moisture content. 


\section{Effects of Living Mulch on Soil Moisture}

Soil moisture content under living mulch is shown in Table 4. According to the table, only LM1, 20.41\%, was slightly higher than $\mathrm{CK}, 20.19 \%, 0.22 \%$ higher; LM2 and LM3 were lower than CK, 20.09\% and $20.11 \%$, respectively. Multiple comparison showed that compared with $\mathrm{CK}$, the soil moisture content of plough layer was not significantly increased by the three living mulches $(p>0.05)$, and there was no significant difference between LM1, LM2 and LM3 $(p>0.05)$. It should be noted that except LM1, soil moisture content of LM2 and LM3 were lower than CK. The reason might be that the root system of alfalfa was deeply buried with less water consumption for topsoil, and that alfalfa canopy could inhibit the evaporation of soil moisture in plough layer, therefore, the soil moisture of LM1 was higher than that of other living mulches as a whole. It could be found that maize intercropping alfalfa had a certain effect on soil moisture conservation. Although maize intercropping with chicory and ryegrass could reduce the evaporation of soil moisture during the maize growing period, their consumption of soil water might be greater, so the effect of them on moisture conservation was not obvious.

\section{Effects of Organic Mulch on Soil Total Organic Carbon, Total Nitrogen, Total Phosphorus and Total Potassium}

\section{Effects of Straw Mulch on Soil Total Organic Carbon, Total Nitrogen, Total Phosphorus and Total Potassium}

Overall, when the straw mulch increased from 0 (CK) to $6.944 \mathrm{Mg} \mathrm{ha}^{-1}$ (SM5), the total organic carbon (TOC) of soil showed an increasing trend, which was 9.89, 24.3, 21.6, 23.1, 30.6 and $31.6 \mathrm{~g} \mathrm{~kg}^{-1}$, respectively, as shown in Fig. 5a). It could be seen that the effect of straw mulch on soil TOC was extremely obvious, and there was a significant positive correlation between straw mulch application rate and soil TOC at the 0.05 significance level $(p<0.05)$, as shown in

Table 4. Multiple comparison of soil moisture content under living mulch.

\begin{tabular}{|c|c|}
\hline Treatment $\uparrow$ & Soil moisture content (\%) \\
\hline CK (Maize monoculture) & $20.19 \pm 1.19 \$ \mathrm{a} \S$ \\
\hline LM1 (Alfalfa intercropping) & $20.41 \pm 0.68 \mathrm{a}$ \\
\hline LM2 (Chicory intercropping) & $20.09 \pm 1.32 \mathrm{a}$ \\
\hline LM3 (Ryegrass intercropping) & $20.11 \pm 1.16 \mathrm{a}$ \\
\hline
\end{tabular}

$\dagger \mathrm{CK}$, no-till with maize monoculture; LM1, no-till with alfalfa intercropping; LM2, no-till with chicory intercropping; LM3, no-till with ryegrass intercropping.

$\$$ Values are the mean \pm SD $(n=46)$.

$\S$ Different lowercase letters mean that there are significant differences between the four treatments at the $\mathrm{P}<0.05$ level.
Table 5. Compared with CK, soil TOC of SM5 increased substantially, nearly 3.2 times. Further significance test showed that compared with $\mathrm{CK}$, different straw mulch application rate increased soil TOC significantly $(p<0.05)$, and there were significant differences between different mulch application rate, such as soil TOC under SM4 and SM5 was significantly higher than that of SM1, SM2 and SM3, but SM5 was not significantly higher than SM4, that was, when the straw mulch increased from 5.556 to $6.944 \mathrm{Mg} \mathrm{ha}^{-1}$, TOC did not increase significantly (Fig. 5a). It could also be seen from the figure that under the condition of SM1, TOC was greater than SM2 and SM3, and significantly higher than SM2. This abnormal situation might be caused by the accumulation of straw in the early stage of straw mulch preparation, which was the same as the aforementioned impact on soil moisture.

Similarly, with the increase of straw mulch application rate, the total nitrogen (TN) also showed an increasing trend on the whole, and the straw mulch application rate and soil $\mathrm{TN}$ showed a significant positive correlation at the level of $0.05(p<0.05)$, as shown in Table 5. When the straw mulch increased from 0 to $6.944 \mathrm{Mg} \mathrm{ha}^{-1}$, the TN increased from 0.56 to $0.99 \mathrm{~g} \mathrm{~kg}^{-1}$, an increase of nearly $77 \%$ (Fig. 5b). Significance test showed that SM1, SM3, SM4 and SM5 significantly increased soil $\mathrm{TN}$ compared to CK $(p<0.05)$. It should be noted that TN did not increase significantly $(p>0.05)$ when the straw mulch increased from SM4 to SM5. In addition, under the condition of SM1, TN was greater than SM2 and SM3, and it was significantly greater than SM2. The possible causes of this abnormal situation were the same as the aforementioned effects on soil moisture and soil TOC. Straw mulch also increased the soil total phosphorus (TP), as shown in Fig. 5b), but with the increase of straw mulch, the trend of TP increase was not as obvious as the TOC and TN mentioned above. Compared with $\mathrm{CK}, 0.557 \mathrm{gkg}^{-1}$, the TP of different straw mulch application rate increased, and the SM1-SM5 were 0.604, 0.790, 0.665, 0.859 and $0.857 \mathrm{~g} \mathrm{~kg}^{-1}$, respectively. Significance test showed that, compared to CK (0 Mg ha $\left.{ }^{-1}\right)$, except SM1 and SM3, SM2, SM4 and SM5 significantly increased soil TP $(p<0.05)$. In addition, the difference of TP between different mulch application rate treatments, especially between high and low straw mulch application rate, was also obvious. For example, TP of SM4 and SM5 was significantly higher than that of SM1 and SM3 $(p<0.05)$, but it should also be noted that SM5 was not significantly higher than that of SM4 $(p>0.05)$.

Different from the above influence trend of straw mulch on TOC, TN and TP, the effect of straw mulch on total potassium (TK) was not very obvious compared with CK, as shown in Fig. 5a). It can be seen that the TK of CK, SM1-SM5 was19.3, 20.3, 19.6, 19.7, 18.9 and $17.1 \mathrm{~g} \mathrm{~kg}^{-1}$, respectively. In general, TK did not show an obvious upward trend with the increase of straw mulch, even SM4 and SM5 showed a downward 
Table 5. Pearson correlation between straw and biochar mulch and soil TOC, TN, TP and TK.

\begin{tabular}{|c|c|c|c|c|}
\hline \multirow{2}{*}{ Organic mulch application rate } & \multicolumn{4}{|c|}{ Soil nutrients $\dagger$} \\
\cline { 2 - 5 } & TOC & TN & TP & TK \\
\hline Straw mulch application rate & $\mathbf{0 . 8 8 1}^{*}$ & $\mathbf{0 . 8 8 5}^{*}$ & 0.749 & -0.727 \\
\hline Biochar mulch application rate & $\mathbf{0 . 8 7 9}^{*}$ & $\mathbf{0 . 9 2 1}^{*}$ & 0.807 & 0.663 \\
\hline
\end{tabular}

$* p<0.05$.

$* * p<0.01$.

$\dagger$ TOC, total organic carbon; TN, total nitrogen; TP, total phosphorus; TK, total potassium.

trend. Significance test showed that compared to CK $\left(0 \mathrm{Mg} \mathrm{ha}^{-1}\right)$, only SM1 and SM3 significantly increased soil TK, while SM2, SM4 and SM5 did not $(p>0.05)$.

\section{Effects of Biochar Mulch on Soil Total Organic Carbon, Total Nitrogen, Total Phosphorus and Total Potassium}

The effects of biochar mulch on TOC, TN, TP and TK of soil were shown in Fig. 6. It could be seen from Fig. 6a) that when the biochar mulch application rate increased from 0 to $11.111 \mathrm{Mg} \mathrm{ha}^{-1}$, TOC generally showed an upward trend, and the TOC of CK, BM1, BM2, BM3 and BM4 were 9.89, 18.8, 31.1, 37.7 and $32.3 \mathrm{~g} \mathrm{~kg}^{-1}$, respectively, with BM3 being the largest. Biochar mulch application rate had a significant positive correlation with soil TOC $(p<0.05)$, as shown in Table 5. Further significance test showed that BM1, BM2, BM3 and BM4 all significantly increased soil TOC compared to $\mathrm{CK}$ $\left(0 \mathrm{Mg} \mathrm{ha}^{-1}\right)$, and there were also significant differences between different biochar mulch application rate, for example, soil TOC under BM3 was significantly higher than that under BM1, BM2 and BM4 $(p<0.05)$.
It should be pointed out that when the biochar mulch reached BM4 (11.111 $\mathrm{Mg} \mathrm{ha}^{-1}$ ), TOC was lower than $\mathrm{BM} 3$, which may be related to the complexity and uncontrollable factors of field test; similarly, with the increase of biochar mulch, the TN was generally on the rise, as shown in Fig. 6b). The effect of biochar mulch on soil TN was also obvious, and there was a significant positive correlation between biochar mulch application rate and TN at the level of $0.05(p<0.05)$. When the biochar mulch application rate was $0 \mathrm{Mg} \mathrm{ha}^{-1}$, the TN was only $0.561 \mathrm{~g} \mathrm{~kg}^{-1}$, while the TN reached the maximum, $1.59 \mathrm{~g} \mathrm{~kg}^{-1}$, under the BM3 mulch condition, it was increased nearly twice, as shown in Fig. 6 b). The significance test showed that compared with $\mathrm{CK}$, BM1, BM2, BM3 and BM4 all significantly increased $\mathrm{TN}(p<0.05)$, and the difference in TN among different mulch application rate was also obvious; biochar mulch also increased soil TP (Fig. 6b), under the condition of CK and BM1-BM4, TP was 0.557, 0.682, 0.679, 0.762 and $0.931 \mathrm{~g} \mathrm{~kg}^{-1}$, respectively, and BM4 reached the largest, increasing about $67 \%$ compared to $\mathrm{CK}$. The significance test showed that, compared with CK, the TP was significantly increased by each mulch application a)

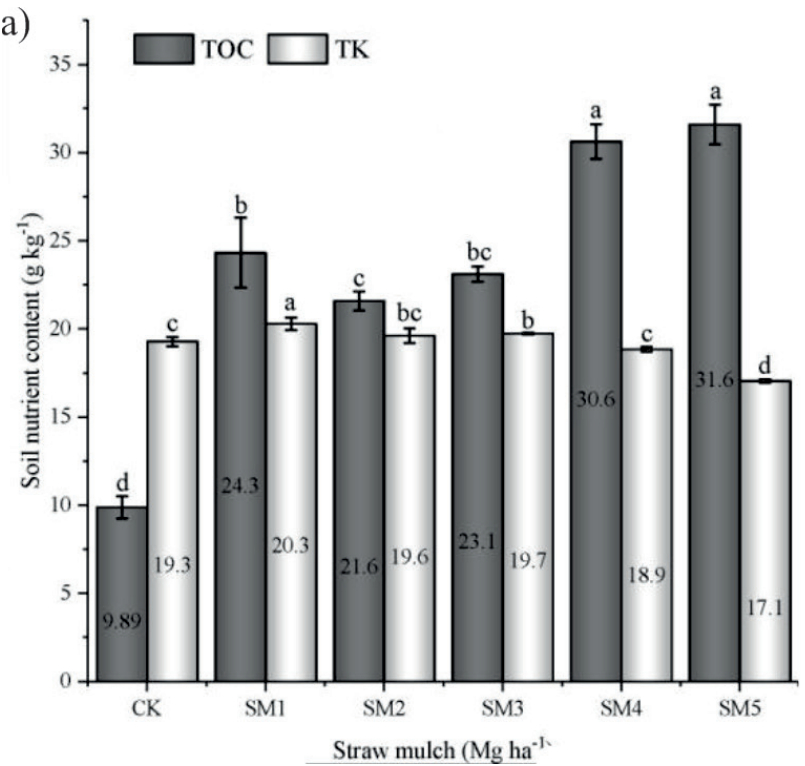

b)

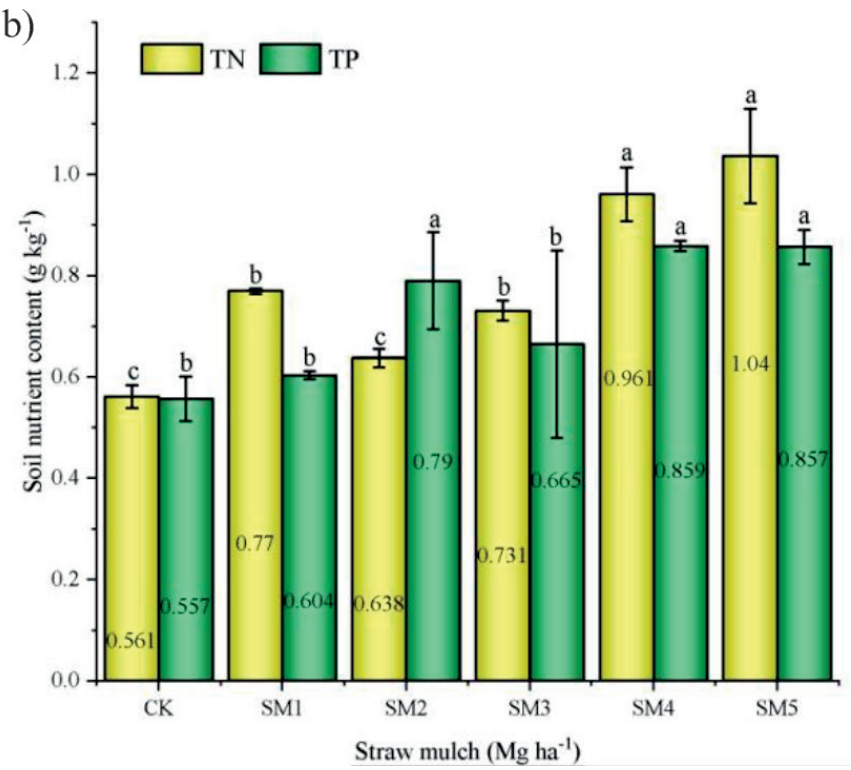

Fig. 5. Multiple comparison of effects of straw mulch on soil total organic carbon (TOC), total nitrogen (TN), total phosphorus (TP) and total potassium $(\mathrm{TK})$. Values are the mean $\pm \mathrm{SD}(\mathrm{n}=3)$. Different lowercase letters mean that there are significant differences between the six treatments at the $\mathrm{P}<0.05$ level. CK no-till without straw mulch, SM1-SM5 no-till with straw mulch application rate from low to high. 
a)

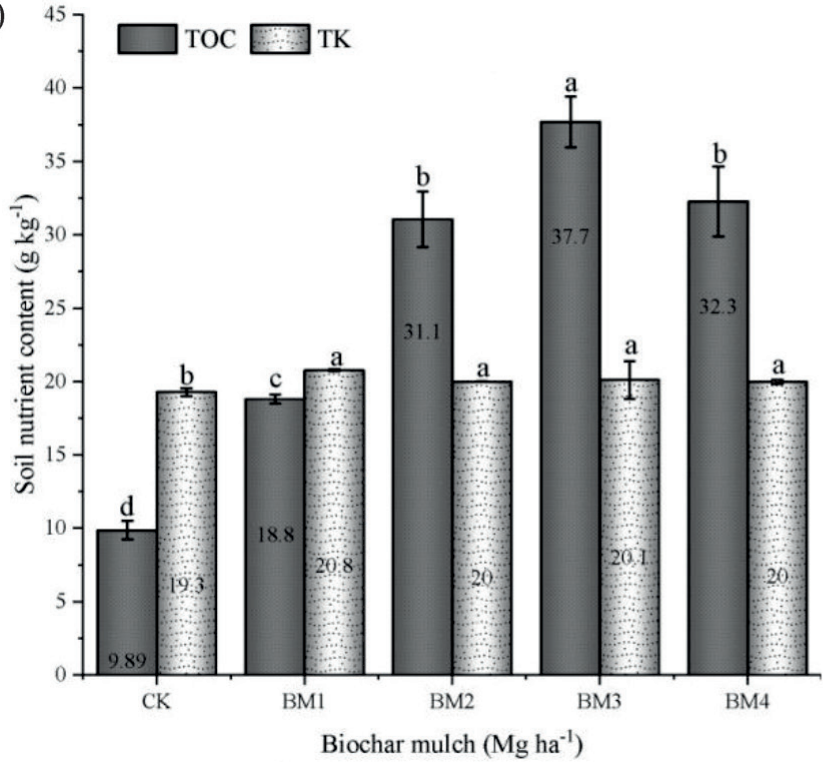

b)

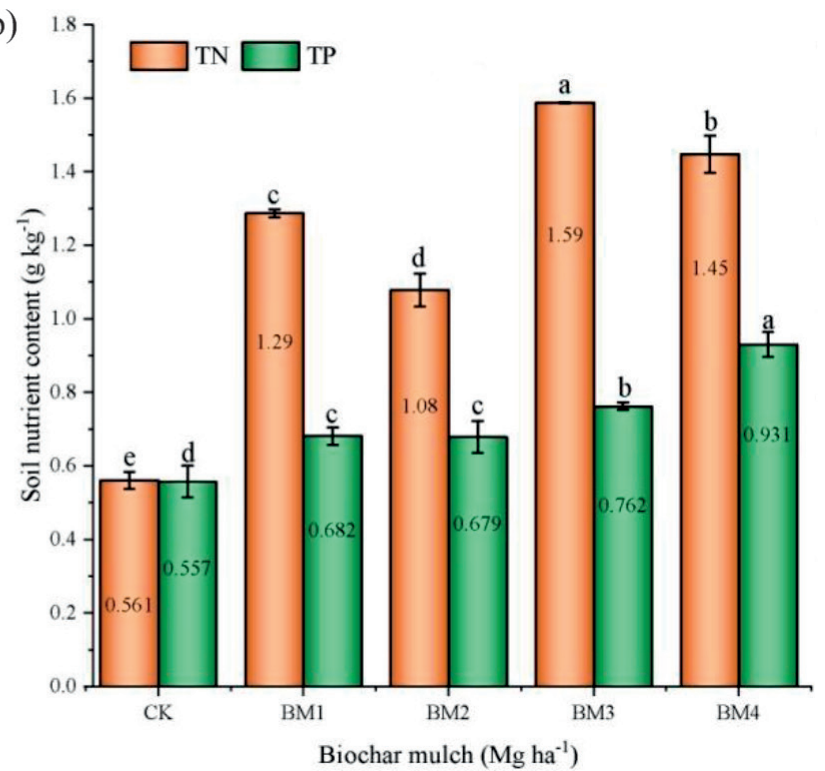

Fig. 6. Multiple comparison of effects of biochar mulch on soil total organic carbon (TOC), total nitrogen (TN), total phosphorus (TP) and total potassium $(\mathrm{TK})$. Values are the mean $\pm \mathrm{SD}(\mathrm{n}=3)$. Different lowercase letters mean that there are significant differences between the five treatments at the $\mathrm{P}<0.05$ level. CK no-till without biochar mulch, BM1-BM4 no-till with biochar mulch application rate from low to high.

rate treatment $(p<0.05)$, and the effect of high biochar mulch application rate on TP was especially obvious. For example, the TP of BM3 and BM4 was significantly higher than that of BM1 and BM2.

Similar to the effects of straw mulch on TK, the continuous increase of biochar mulch had little effect on TK. The content of TK under CK and BM1-BM4 was $19.3,20.8,20.0,20.1$ and $20.0 \mathrm{~g} \mathrm{~kg}^{-1}$, respectively, as shown in Fig. 6a). The significance test showed that BM1, BM2, BM3 and BM4 all significantly increased
TK $(p<0.05)$ compare to CK, but with the continuous increase of biochar mulch, TK did not increase significantly, that is, there was no significant difference in TK among BM1, BM2, BM3 and BM4 $(p>0.05)$.

\section{Effects of Living Mulch on Soil Total Organic Carbon, Total Nitrogen, Total Phosphorus and Total Potassium}

The effects of living mulch on soil TOC, TN, TP and TK was shown in Fig. 7. It could be seen from
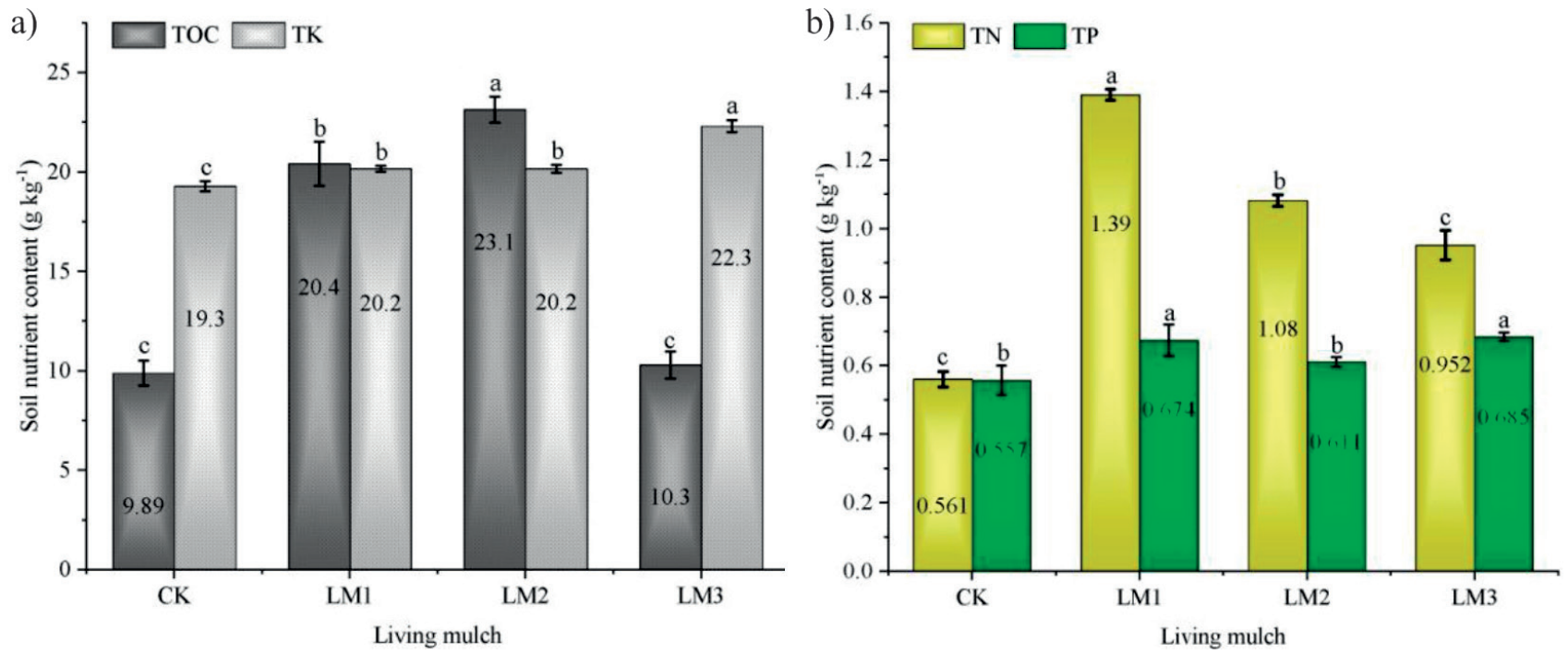

Fig. 7. Multiple comparison of the effects of living mulch on soil total organic carbon (TOC), total nitrogen (TN), total phosphorus (TP) and total potassium $(\mathrm{TK})$. Values are the mean $\pm \mathrm{SD}(\mathrm{n}=3)$. Different lowercase letters mean that there are significant differences between the four treatments at the $\mathrm{P}<0.05$ level. CK no-till with maize monoculture, LM1 no-till with alfalfa intercropping, LM2 no-till with chicory intercropping, LM3 no-till with ryegrass intercropping. 
Fig. 7a) that LM1 and LM2 had obvious effects on soil TOC. Under LM2 treatment, TOC reached the maximum, $23.1 \mathrm{~g} \mathrm{~kg}^{-1}$, which was 2.34 times higher than CK, $9.89 \mathrm{~g} \mathrm{~kg}^{-1}$. Significance test showed that both LM1 and LM2 significantly increased soil TOC content compared with CK $(p<0.05)$, but LM3 did not $(p>0.05)$. At the same time, the difference of TOC among the three living mulch treatments was significant $(p<0.05)$, in which TOC under LM2 was significantly higher than that under LM1 and LM3; The effects of living mulch on soil TK was also obvious, the TK content of CK, LM1, LM2 and LM3 were 19.3, 20.2, 20.2 and $22.3 \mathrm{~g} \mathrm{~kg}^{-1}$, respectively, and the TK under LM3 was the highest, $22.3 \mathrm{~g} \mathrm{~kg}^{-1}$, nearly 16 percentage points higher than that of $\mathrm{CK}$. The significance test showed that, compared to $\mathrm{CK}$, the soil TK was significantly increased by the three living mulch treatments $(p<0.05)$ and the effect of LM3 on TK was particularly obvious, with soil TK significantly higher than that of LM1 and LM2; the effect of living mulch on soil TN was shown in Fig. 7b). It was known from the figure that three kinds of living mulches have greatly increased the content of soil $\mathrm{TN}$, from $0.561 \mathrm{~g} \mathrm{~kg}^{-1}$ (CK) to $1.39,1.08$ and $0.952 \mathrm{~g} \mathrm{~kg}^{-1}$ respectively, among which LM2 had the most obvious effect on TN, increasing $\mathrm{TN}$ by nearly 2.5 times compared to $\mathrm{CK}$. The significance test showed that compared with $\mathrm{CK}$, the soil $\mathrm{TN}$ was significantly increased by LM1 and LM2 $(p<0.05)$, while LM3 did not $(p>0.05)$. In addition, there were significant differences in TN among the three living mulch treatments $(p<0.05)$; the effect of living mulch on soil TP was shown in Fig. 7b), it could be seen that soil TP under three kinds of living mulches has increased to a certain extent, from $0.557 \mathrm{~g} \mathrm{~kg}^{-1}$ to $0.674,0.611$ and $0.685 \mathrm{~g} \mathrm{~kg}^{-1}$, respectively. The significance test showed that compared to CK, LM1 and LM3 significantly increased soil TP content, while LM2 did not $(p>0.05)$.

\section{Comparison of Effects of Three Organic Mulches on Soil Moisture and Nutrient Contents}

Fig. 8a) showed the effects of three organic mulches on soil moisture. Under the conditions of straw, biochar and living mulch, the mean value of soil moisture content was 20.8, 20.26 and $20.2 \%$, respectively. Obviously, the moisture content of straw mulch was the highest, up to $20.8 \%$, and the living mulch was the lowest, $20.2 \%$. The significance test showed that there was no significant difference among the three organic mulches $(p>0.05)$.

As shown in Fig. 8a), the mean value of soil TOC under straw mulch (SM), biochar mulch (BM) and living mulch (LM) was 26.3, 30 and $18 \mathrm{~g} \mathrm{~kg}^{-1}$, respectively. Obviously, under the conditions of straw and biochar mulch, the TOC content of soil was much higher than that of living mulch, and the soil TOC under biochar mulch was the largest, $30 \mathrm{~g} \mathrm{~kg}^{-1}$, about 67 percentage points higher than that of living mulch. Significance test showed that TOC under SM and BM was significantly higher than that under LM $(p<0.05)$, but there was no significant difference between SM and BM $(p>0.05)$; TK under three kinds of organic mulches was shown in Fig. 8b), and mean value of soil TK under SM, BM and LM was 19.1, 20.2 and $20.9 \mathrm{~g} \mathrm{~kg}^{-1}$, respectively. It could be seen that there was little difference in TK among the three organic mulches, and the difference value between the highest, LM, 20.9 $\mathrm{g} \mathrm{kg}^{-1}$, and the lowest, SM, $19.1 \mathrm{~g} \mathrm{~kg}^{-1}$, was only $1.8 \mathrm{~g}$ $\mathrm{kg}^{-1}$. In fact, it was known from the previous analysis that the effect of three organic mulches on soil TK was not very obvious. The significance test showed that soil TK of living mulch and biochar mulch was significantly
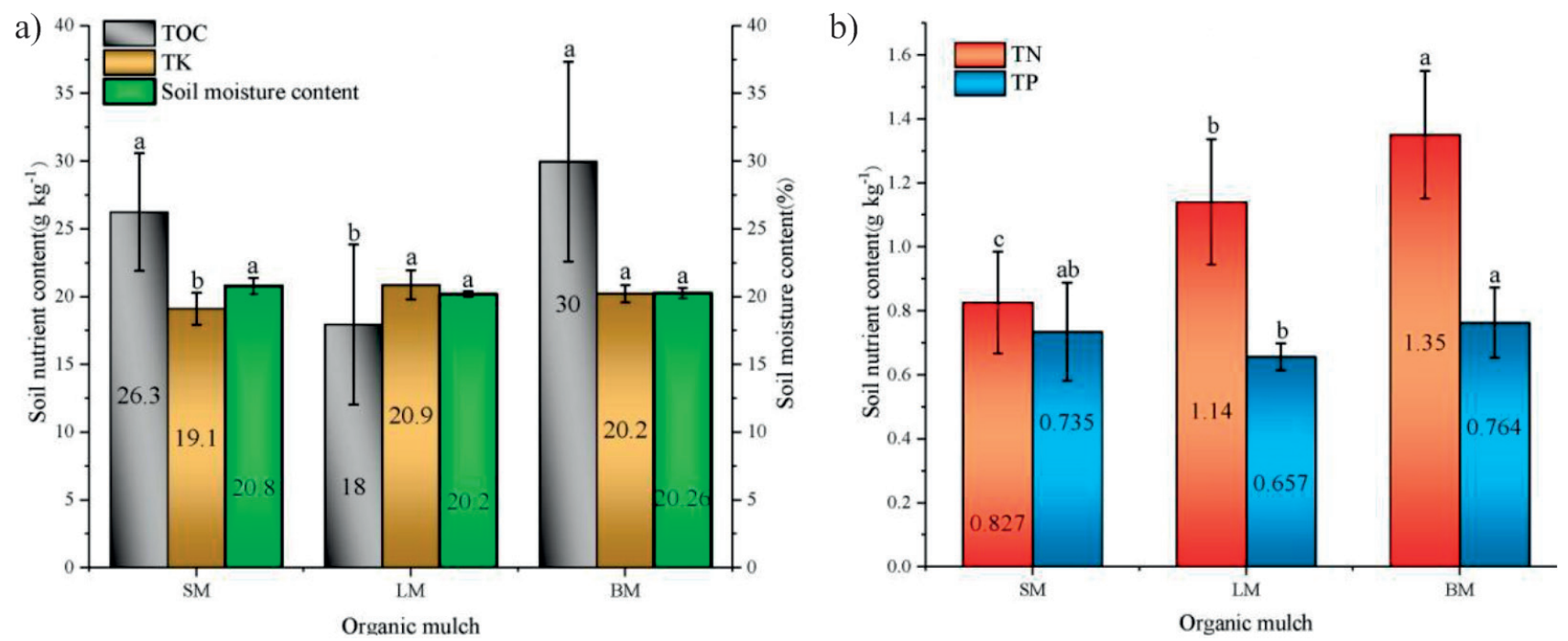

Fig. 8. Multiple comparison of the effects of three organic mulches on soil moisture and soil total organic carbon (TOC), total nitrogen (TN), total phosphorus (TP) and total potassium (TK). Values are the mean \pm SD. Different lowercase letters mean that there are significant differences between the three organic mulches at the $\mathrm{P}<0.05$ level. SM straw mulch, LM living mulch, BM biochar mulch. 
higher than that of straw mulch $(p<0.05)$, but there was no significant difference between LM and BM $(p>0.05)$; the effect of organic mulch on soil TN was shown in Fig. 8a), and mean value of soil TN under SM, BM and $\mathrm{LM}$ was $0.827,1.35$ and $1.14 \mathrm{~g} \mathrm{~kg}^{-1}$, respectively. Obviously, biochar mulch had a prominent effect on $\mathrm{TN}$, reaching $1.35 \mathrm{~g} \mathrm{~kg}^{-1}, 63 \%$ and $18 \%$ higher than straw and living mulch respectively. The significance test showed that there was a significant difference in TN among SM, LM and BM $(p<0.05)$; From Fig. 8b), it could be found that mean value of soil TP was $0.735,0.764$ and $0.657 \mathrm{~g} \mathrm{~kg}^{-1}$ respectively under straw, biochar and living mulch conditions, $\mathrm{BM}>\mathrm{SM}>\mathrm{LM}$. The significance test showed that TP under biochar mulch was significantly higher than that under living mulch $(p<0.05)$, but not significantly higher than straw mulch $(p>0.05)$, and there was no significant difference between straw mulch and living mulch $(p>0.05)$.

\section{Discussions}

\section{Effects of Straw Mulch on Soil Total Potassium}

Crop straw contains a large amount of nitrogen, phosphorus, potassium and other nutrients, and the potassium resource accounts for about $1.5 \%$ of the weight of straw dry matter; the potassium of straw mainly exists in the ionic state, which is easy to be dissolved and supplied to crops for absorption and utilization, so straw mulching can improve the content of soil available potassium, thus improving the quality of cultivated land [27-30]. However, this study founded that compared with traditional maize monoculture, low straw mulch application rate significantly increased soil total potassium content, but when straw mulch application rate continued to increase, soil total potassium content did not show an upward trend, on the contrary, there was a downward trend. The potassium in straw cannot be directly absorbed and utilized by crops, but it can be released in the form of ion through the leaching of soil water and precipitation in the process of degradation [31-32]. Therefore, higher soil moisture content is not only conducive to straw degradation, but also the conversion and release of potassium in the easily hydrolyzed part, what more, it also greatly improves the absorption efficiency of crops to available potassium in soil [33].

In addition, it is also found that in tropical,soil potassium dynamics depend on soil type, texture, $\mathrm{PH}$, soil cation exchange capacity, and the ratio of calcium $\left(\mathrm{Ca}^{+2}\right)+$ magnesium $\left(\mathrm{Mg}^{+2}\right) / \mathrm{K}$ [34]. Under the same soil total potassium content, when the cation exchange capacity of the soil is high, the potassium in the soil solution decreases, which causes the decreases in the loss of potassium and the absorption of potassium by plants, while the storage of potassium in the soil increases [35]. On the contrary, when the soil cation exchange capacity is low and the potassium concentration in the soil solution and the soil moisture content are high, the soil potassium will leach to the deeper soil layer. Therefore, the leaching amount of potassium depends on the potassium concentration in the soil solution and the soil moisture content [34]. In this study, it has been confirmed that with the increase of straw mulch, the soil moisture condition has been improved continuously, especially under the conditions of SM4 and SM5. Therefore, it can be inferred that the decrease of total potassium with the continued increase of straw mulch may be due to the low cation exchange capacity, the high content of soil moisture and the high concentration of potassium in soil solution under high straw mulch application rate, which aggravates the leaching loss of soil potassium to the subsoil. It can be found that in the study of the effects of organic mulch on soil nutrient content in the karst area of Southwest China, the hydrological, geological and climatic environment are important factors that cannot be ignored.In addition, this phenomenon may be related to the thickness of straw mulch and the length of mulching time. Under the condition of this experiment, straw was directly mulched on the surface of the soil, and the mulching time was just one crop growth period. Therefore, in the case of thick straw mulching layer, because the upper straw had less contact with the soil and soil water, the upper straw would dry up rapidly due to the rapid evaporation of water under high temperature conditions, leading to straw decomposition only in the lower layer [33].

\section{Straw Mulch Application Rate}

The improvement effect of organic mulch on soil moisture condition has been widely confirmed [36-38]. However, due to the differences of natural environment, length of test observation and mulching materials in each study area, the appropriate straw mulch application rate based on good soil moisture conservation effect is still not uniform. When Mulumba and Lal studied the effects of straw mulch on soil physical properties in Ohio, USA, it was found that the soil moisture content increased with the increase of straw mulch, but after more than $8 \mathrm{Mg} \mathrm{ha}^{-1}$, the soil moisture did not increase significantly, so they thought $8 \mathrm{Mg} \mathrm{ha}^{-1}$ was the suitable mulching application rate [39]; when studying the effects of different straw mulch application rate on water storage and water conservation of spring maize field in the dryland area of North Wei River in China, it was considered that $9 \mathrm{Mg} \mathrm{ha}^{-1}$ was the appropriate straw mulch application rate for spring maize in the dryland of North Wei River and the similar ecological area in combination with the grain yield and water conservation benefits of straw mulch [40]; however, in this study, based on the short-term organic mulch experiment, it was found that the soil moisture content did not increase significantly when the straw mulch application rate exceeds $5.556 \mathrm{Mg} \mathrm{ha}^{-1}$. Organic mulch and its decomposition products can 
improve soil structure and soil water infiltration rate by enhancing soil aggregate stability and increasing soil porosity [41-43], but it should be noted that the continuous increase of straw mulch may impart water repellent and hydrophobic properties to the soil surface and restrict water infiltration [44]. This further indicates that although straw mulch plays an important role in soil moisture conservation, there is not a simple positive proportional linear relationship between straw mulch application rate and soil moisture content.

Soil nutrient content is closely related to straw mulch application rate. Overall, with the increase of straw mulch, the content of soil organic carbon, mineral carbon, exchangeable potassium, available phosphorus and other nutrients tends to increase [42, 45]; increasing straw mulch has certain effect on increasing soil organic carbon content, but organic carbon storage depends mainly on soil texture and structure, and the finer fraction of soil (silt and clay) plays an important role in stabilizing soil organic carbon [46-47]. In addition, studies have also shown that straw mulch effect on enzymes activities was strongly dependent on mulching levels and some adverse effects at straw mulch higher than $15 \mathrm{Mg} \mathrm{ha}^{-1}$ were observed [48]. It indicates that in the practice of straw mulch, straw mulch application rate is not the final determinant of soil nutrient content, and the effect of straw mulch on soil nutrient is greatly different due to different climatic conditions, mulching methods and initial content of soil nutrient [49, 50]. Based on the main results of this study and considering the economic cost of straw mulch, we believed that $6 \mathrm{Mg} \mathrm{ha}^{-1}$ may be a reasonable straw mulch application rate in the karst area of Southwest China, which could be used as a reference for regional organic mulching practice.

\section{Conclusions}

1) Overall, with the increase of straw mulch, the soil moisture increased, but when the straw mulch exceeded $5.556 \mathrm{Mg} \mathrm{ha} \mathrm{ha}^{-1}$, the soil moisture was no longer significantly increased; biochar and living mulch did not significantly increase the soil moisture. The effect of straw mulch on moisture conservation was better than that of biochar and living mulch.

2) Under the condition of high straw and biochar mulch application rate, the TOC, TN and TP were significantly higher than those under control, in which TOC and TN were positively correlated with straw and biochar mulch application rate, but the continued increase of straw and biochar mulch had no significant effect on TK; as a legume plant, soil TN under alfalfa intercropping (LM1) was significantly higher than that of the control, chicory and ryegrass intercropping (LM2, LM3). Among the three types of organic mulches, the soil TOC of straw and biochar mulch was higher than that of living mulch; in addition, the effect of biochar mulch on soil TN and TP was obvious, and both TN and TP reached the maximum, it was significantly higher than that of living mulch; although soil TOC, TN and TP under the living mulch was lower, the soil TK under living mulch was higher than that of straw mulch.

3) Straw, biochar and living mulch could improve soil nutrients and moisture condition to a certain extent, but in terms of short-term organic mulch and the low cost and easy availability of mulching materials, and based on the effect of straw mulch on soil moisture and fertility, we believed that straw mulch was a suitable organic mulch in karst area, and straw mulch of $6 \mathrm{Mg} \mathrm{ha}^{-1}$ might be a reasonable reference mulching application rate of sloping farmland in karst area of Southwest China.

\section{Acknowledgements}

The authors are grateful for support by the National Natural Science Foundation of China (31760243); the Technology Research and Development Program of Guizhou Province (Qiankehe Zhicheng [2019] 2847); the Basic Research Foundation of Guizhou Province (Qiankehe Jichu [2018]1112); the Foundation of Guizhou Water Resources Department (KT201806).

\section{Conflict of Interest}

The authors declare no conflicts of interest.

\section{References}

1. BAI Z.G., DENT D.L., OLSSON L., SCHAEPMAN M.E. Global assessment of land degradation and improvement: 1. identification by remote sensing. Report 2008 (01), ISRIC-World Soil Information, Wageningen, Find this resource, 2008.

2. ZHANG T.L., WANG X.X. Progress and trend of soil degradation research. Journal of Natural Resources, 3, $280,2000$.

3. CHENG M., ZHOU H.P. Effects of long-term straw returning to the field on soil nutrients, enzyme activity and corn yield in the Loess Plateau. Chinese Journal of EcoAgriculture, 27 (10), 1528, 2019.

4. RAMARKRISHNA A., TAM H.M., WANI S.P., WANI S.P., LONG T.D. Effect of mulch on soil temperature, moisture, weed infestation and yield of groundnut in northen Vietnam. Field Crops Research, 95 (2-3), 115, 2006.

5. LI R., WU Q., ZHANG J., WEN Y., LI Q. Effects of land use change of sloping farmland on characteristic of soil erosion resistance in typical karst mountainous areas of southwestern China. Polish Journal of Environmental Studies, 28 (4), 2707, 2019.

6. ADHIKARI R., BRISTOW K.L., CASEY P.S., FREISCHMIDT G., HORNBUCKLE J.W., ADHIKARI B. Preformed and sprayable polymeric mulch film to 
improve agricultural water use efficiency. Agricultural Water Management, 169, 1, 2016.

7. KADER M.A., SENGE M., MOJID M.A., ITO K. Recent advances in mulching materials and methods for modifying soil environment. Soil and Tillage Research, 168, 155, 2017.

8. HARTWIG N.L., AMMON H.U. Cover crops and living mulches. Weed science, 50 (6), 688, 2002.

9. BAI S.H., BLUMFIELD T.J., REVERCHON F. The impact of mulch type on soil organic carbon and nitrogen pools in a sloping site. Biology and fertility of soils, $\mathbf{5 0}$ (1), 37, 2014.

10. LI Y., JIANG P., CHANG S.X., WU J., LIN L. Organic mulch and fertilization affect soil carbon pools and forms under intensively managed bamboo (Phyllostachys praecox) forests in southeast China. Journal of Soils and Sediments, 10 (4), 739, 2010.

11. ZHAO S.C., CAO C.Y., LI K.J., QIU S.J., ZHOU W., HE P. Effect of long-term straw returning to the field on the fertility, nitrogen pool components and crop yield of North China tidal soil. Journal of Plant Nutrition and Fertilizers, 20 (6), 1441, 2014.

12. CHAUHAN B.S., SINGH R.G., MAHAJAN G. Ecology and management of weeds under conservation agriculture: a review. Crop Protection, 38, 57, 2012.

13. KATHRIN G., NELEV., KLAUS D., BRAM G., ANDREAS B.High $\mathrm{n}$ fertilizer application to irrigated wheat in northern Mexico for conventionally tilled and permanent raised beds: effects on $\mathrm{n}$ balance and short term $\mathrm{n}$ dynamics. Journal of Plant Nutrition and Soil Science, 181(4), 606, 2018.

14. XIONG K.N., CHI Y.K., SHEN, X.Y. Research on photosynthetic leguminous forage in the karst rocky desertification regions of southwestern China. Polish Journal of Environmental Studies, 26 (5), 2319, 2017.

15. SALAMON J.A., WISSUWA J., JAGOS S., KOBLMÜLLER M., OZINGER O., WINKLER C., FRANK T. Plant species effects on soil macrofauna density in grassy arable fallows of different age. European Journal of Soil Biology, 47 (2), 129, 2011.

16. NIE Y.Y., CHEN T., LV M.K., ZHANG K.J., ZENG M., DENG C., REN Y.B., XIE J.S. Effect of Osmunda coverage on nitrogen components in eroded red soil during vegetation restoration. Acta Ecologica Sinica, 38 (19), 6964, 2018.

17. XU Q.X., WANG T.W., CAI C.F., LI Z.X., SHI Z.H. Effects of soil conservation on soil properties of citrus orchards in the Three - Gorges area, China. Land Degradation and Development, 23 (1), 34, 2012.

18. ZHU Q., CHEN Z.G., LI J., XIONG Y.H. Comparative study on soil and water conservation effects of three planting patterns on slope land in Guizhou. Research of Soil and Water Conservation, 19 (4), 21, 2012.

19. DU S., BAI G., YU J. Soil properties and apricot growth under intercropping and mulching with erect milk vetch in the loess hilly-gully region. Plant and Soil, 390 (1-2), 431, 2015.

20. COOK H.F., VALDES G.S., LEE H.C. Mulch effects on rainfall interception, soil physical characteristics and temperature under Zea mays L. Soil and tillage research, 91 (1), 227, 2006.

21. OLIVEIRA M.T., MERWIN I.A. Soil physical conditions in a New York orchard after eight years under different groundcover management systems. Plant and Soil, 234 (2), 233, 2001.
22. LARENTZAKI E., PLATE J., NAULT B.A., SHELTON A.M. Impact of straw mulch on populations of onion thrips (Thysanoptera:Thripidae) in onion. Journal of economic entomology, 101 (4), 1317, 2008.

23. JORDÁN A., ZAVALA L.M., GIL J. Effects of mulching on soil physical properties and runoff under semi-arid conditions in southern Spain. Catena, 81(1), 77, 2010.

24. KADER M.A., SINGHA.A., BEGUM M.A., JEWEL A., KHAN F.H., KHAN N.I. Mulching as water-saving technique in dryland agriculture: review article. Bulletin of the National Research Centre, 43 (1), 1, 2019.

25. RANAIVOSON L., NAUDIN K., RIPOCHE A., AFFHOLDER F., RABEHARISOA L., CORBEELS M. Agro-ecological functions of crop residues under conservation agriculture. A review. Agronomy for Sustainable Development, 37 (4), 1, 2017.

26. NAWAZ A., LAL R., SHRESTHA R.K., FAROOQ M. Mulching affects soil properties and greenhouse gas emissions under long-term no-till and plough-till systems in alfisol of Central Ohio. Land degradation and development 681, 673, 2017.

27. RIMMER D.L., MCKENNA B.A., VAUGHAN S.M., MENZIES N.W. Antioxidant capacity and rate of decomposition of organic amendments in a vertisol. European Journal of Soil Science, 64(1), 104, 2013.

28. BENBI D.K., YADAV S.K.Decomposition and carbon sequestration potential of different rice residue-derived by-products and farmyard manure in a sandy loam soil. Communications in Soil Science and Plant Analysis, 46(17), 2274, 2015.

29. LI S.T., JIN J.Y. Input, output and balance of farmland nutrients in different regions of China. Scientia Agricultura Sinica, 44 (20), 4207, 2011.

30. NOACK S.R., MCBEATH T.M., MCLAUGHLIN M.J., SMERNIK R.J., ARMSTRONG R.D. Management of crop residues afects the transfer of phosphorus to plant and soil pools: results from a dual-labelling experiment. Soil Biology and Biochemistry, 71, 31, 2014.

31. LI J.F., LU J.W., LI X.K., REN T., CONG R., ZHOU L. Dynamics of potassium release and adsorption on rice straw residue. Plos One, 9 (2), e90440, 2014.

32. MAO H.L., FU X., ZHAO D.D., LI R.R., WANG J.U.N. seasonal dynamics of soil nitrogen components in dry corn field under straw and plastic film mulching. Journal of Soil and Water Conservation, 32 (4), 246, 2018.

33. YAN F.J., SUN Y.J., HUI X., JIANG M.J., XIANG K.H., WU Y.X., ZHANG Q., TANG Y., YANG Z.Y., SUN Y.Y., MA J. The effect of straw mulch on nitrogen, phosphorus and potassium uptake and use in hybrid rice. Paddy and Water Environment, 17 (1), 23, 2019.

34. ROSOLEM C.A., SGARIBOLDI T., GARCIA R.A., CALONEGO J.C. Potassium leaching as affected by soil texture and residual fertilization in tropical soils. Communications in Soil Science and Plant Analysis, 41 (16), 1934, 2010.

35. SADRI N., OWLIAIE H.R., ADHAM, E., GHIRI M N. Investigation of different forms of potassium as a function of clay mineralogy and soil evolution in some soils of fars province. Majallah-iāb va Khāk, 30 (1), 172, 2016.

36. SIDOROVA M.A., BORISOVA E.O. Features of the moisture regime of a model sod-podzolic soil when mulching with spruce litter. Moscow University Soil Science Bulletin, 69 (2), 78, 2014.

37. AWE G.O., REICHERT J.M., TIMM L.C., WENDROTH O.O. Temporal processes of soil water status in a sugarcane 
field under residue management. Plant and Soil, 387 (1-2), 395, 2015.

38. YIN M., LI Y., XU Y., ZHOU C. Effects of mulches on water use in a winter wheat/summer maize rotation system in Loess Plateau, China. Journal of Arid Land, 10 (2), 277, 2018.

39. MULUMBA L.N., LAL R. Mulching effects on selected soil physical properties. Soil and Tillage Research, 98 (1), 106, 2008.

40. CAI T.Y., JIA Z.K., HUANG Y.W., HUANG H.J., MENG L., YANG B.P., LI H. Effects of different straw mulches on water conservation and water saving efficiency in spring maize fields. Transactions of the Chinese Society of Agricultural Engineering, 27 (13), 238, 2011.

41. GAO S.J., GAO J.S., CAO W.D., ZOU C.Q., DOU F.G. Effects of long-term green manure application on the content and structure of dissolved organic matter in red paddy soil.Journal of Integrative Agriculture, 17 (8), 1852, 2018.

42. FU X., WANG J., LIU Q.Q., LI R.R. Changes of soil aggregate and organic carbon content in different mulching materials and dry farming methods. Journal of Plant Nutrition and Fertilizers, 21 (6), 1423, 2015.

43. LI X.H., GUO H.H., ZHU Z.L., DONG H.Y., YANG L.P., ZHANG X.J. Effects of different straw returning modes on soil organic carbon and its active components. Transactions of the Chinese Society of Agricultural Engineering, 32 (9), 130, 2016.

44. SHARRATT B., ZHANG M., SPARROW S. Twenty years of conservation tillage research in subarctic Alaska:
II. Impact on soil hydraulic properties. Soil and Tillage Research, 91 (1-2), 82, 2006.

45. WU X.H., WANG W., XIE X.L., YIN C.M., HOU H.J. Effects of rice straw mulching on $\mathrm{N}_{2} \mathrm{O}$ emissions and maize productivity in a rain-fed upland. Environmental Science and Pollution Research, 25 (7), 6407, 2018.

46. RUQIN F., XUEMING Y., DRURY C.F. Curve-fitting techniques improve the mid-infrared analysis of soil organic carbon: a case study for Brookston clay loam particle-size fractions. Scientific Reports, 8 (1), 12174, 2018.

47. JAGADAMMA S., LAL R. Distribution of organic carbon in physical fractions of soils as affected by agricultural management. Biology and Fertility of Soils, 46 (6), 543, 2010.

48. ZHANG X., QIAN Y., CAO C. Effects of straw mulching on maize photosynthetic characteristics and rhizosphere soil micro-ecological environment. Chilean journal of agricultural research, 75 (4), 481, 2015.

49. RASMUSSEN P.E., COLLINS H.P. Long-term impacts of tillage, fertilizer, and crop residue on soil organic matter in temperate semiarid regions. Advances in agronomy, 45 (45), 93, 1991.

50. HOOKER B.A., MORRIS T.F., PETERS R., CARDON Z.G. Long-term effects of tillage and corn stalk return on soil carbon dynamics. Soil Science Society of America Journal, 69 (1), 188, 2005. 